\title{
Identifikasi Penyakit Pada Terumbu Karang Menggunakan Ripple Down Rules
}

\author{
Agus Cahyo Nugroho \\ Teknik Informatika, Universitas Ciputra \\ UC Town, Citraland, Made, Sambikerep, Surabaya, Jawa Timur \\ agus.nugrohodciputra.ac.id
}

\begin{abstract}
Along with the development of technology, people developed a system that capable of adopting processes and human thinking as an expert system that contains specific knowledge so that everyone can use it to solve a specific problem, namely the diagnosis of coral reef disease. The purpose of this study is to develop an expert system for diagnosing coral reef disease in the form of websites using PHP with a MySQL database. Expert system for diagnosing coral reef disease problem is using Ripple Down Rules (RDR) method has a goal to discover symptoms that appear in the form of questions that can diagnose the coral reef disease based on website. Web based expert system is able to recognize types of coral reef disease after consultation by answering a few questions that are displayed by the application of expert systems and can infer some types of coral reef disease. Data coral reef disease that already known adapt to rules which are made for matching the symptoms of coral reef disease.
\end{abstract}

Seiring perkembangan teknologi, dikembangkan sebuah sistem yang mampu mengadopsi proses dan cara berpikir manusia yaitu sistem pakar yang mengandung pengetahuan tertentu sehingga setiap orang dapat menggunakannya untuk memecahkan masalah bersifat spesifik yaitu permasalahan diagnosis penyakit pada terumbu karang. Tujuan dari penelitian ini adalah membangun sistem pakar untuk mendiagnosa penyakit pada terumbu karang dalam bentuk website menggunakan pemrograman PHP dengan database MySQL. Sistem pakar untuk mendiagnosa penyakit pada terumbu karang menggunakan metode Ripple Down Rules (RDR) ini bertujuan menelusuri gejala yang ditampilkan dalam bentuk pertanyaan - pertanyaan agar dapat mendiagnosa jenis penyakit dengan berbasis website. Sistem pakar berbasis web mampu mengenali jenis penyakit pada terumbu karang setelah melakukan konsultasi dengan menjawab beberapa pertanyaan - pertanyaan yang ditampilkan oleh aplikasi sistem pakar serta dapat menyimpulkan beberapa jenis penyakit pada terumbu karang. Data penyakit yang dikenali menyesuaikan rules (aturan) yang dibuat untuk dapat mencocokkan gejala-gejala penyakit pada terumbu karang.

Kata Kunci- sistem pakar, penyakit terumbu karang, ripple down rules, forward chaining

\section{PENDAhUluan}

\section{A. Latar Belakang}

Sistem pakar adalah sistem yang menggabungkan pengetahuan, fakta, aturan dan teknik penelusuran untuk memecahkan masalah yang secara normal memerlukan keahlian seorang pakar [1].

Sistem pakar yang ada saat ini mengalami permasalahan dalam pengembangan dan pemeliharaan sistem. Masalah itu disebabkan oleh akusisi pengetahuan dari pakar yang hanya dilakukan pada awal pembangunan sistem pakar, sehingga membuat sistem tidak dapat mengatasi setiap masalahmasalah baru yang muncul karena tidak terdapat fakta-fakta dan aturan untuk mengatasi permasalahan tersebut. Masalah lain yang terjadi adalah sistem pakar tidak dapat mengubah fakta-fakta dan aturan yang ada, karena dapat merusak basis aturan yang sudah terbentuk sebelumnya.

Penulis mencoba melakukan sebuah penelitian dengan menggunakan metode Ripple Down Rules (RDR) untuk menyelesaikan masalah yang terjadi. Metode Ripple Down Rules (RDR) merupakan suatu metode untuk akusisi pengetahuan baru dari seorang pakar ke dalam sistem dan berdasarkan akusisi pengetahuan tersebut sistem secara mandiri membuat aturan-aturan baru, dimana posisi aturan baru tersebut disesuaikan dengan basis aturan dari aturanaturan yang sudah ada. Selain itu jika pakar menganggap pengetahuan yang dimasukan ke dalam sistem tidak sesuai dengan pemikirannya, maka metode Ripple Down Rules $(R D R)$ ini juga memperbolehkan pakar untuk menghapus ataupun mengganti pengetahuan yang sudah ada sehingga sistem ini dapat selalu memiliki pengetahuan yang benar dan terbaru yang dimiliki oleh pakar.

Terumbu karang yang merupakan objek penelitian adalah hewan bentik yang hidup di dasar perairan. Hewan ini sebagian besar hidupnya berkoloni yang tersusun atas Kalsium karbonat ( $\mathrm{CaCO} 3$ ) sebagai hasil sekresi dari Zooxanthellae. Terumbu karang merupakan habitat berbagai biota laut untuk tumbuh dan berkembang biak dalam kehidupan yang seimbang. Sadarun [2] menyatakan bahwa sifat yang menonjol dari terumbu karang adalah keanekaragaman, jumlah spesies, dan bentuk morfologinya yang tinggi dan bervariasi. Salah satu sifat dari ekosistem terumbu karang adalah kerentanan ekosistem tersebut menerima dampak dari luar. Sebagai contoh kerusakan terumbu karang akibat faktor antropogenik, faktor alami, maupun dari penyakit karang itu sendiri dapat menurunkan persentase tutupan karang hidup di suatu perairan. Menurut Kurman [3] menunjukkan hasil bahwa tutupan karang hidup di Indonesia hanya sekitar 5\% dalam keadaan bagus dengan persen cover 50-75.

Selanjutnya menurut Willis et al. [4] penyakit karang memberikan sumbangsih terbesar kematian karang di Perairan Australia khususnya di Great Barrier Reef. Lebih lanjut Kellogg et al. [5] mengungkapkan bahwa di pantai Florida AS juga mengindikasikan bahwa kematian karang terbesar diakibatkan oleh mikroorganisme yang menyebabkan penyakit karang. Penyakit karang adalah 
gangguan terhadap kesehatan karang yang menyebabkan gangguan secara fisiologis bagi biota karang [6]. Munculnya penyakit karang dicirikan dengan adanya perubahan warna, kerusakan dari skeleton biota karang, sampai dengan kehilangan jaringannya. Munculnya penyakit tersebut merupakan interaksi antara host atau inang dalam hal ini biota karang, agent/pembawa dalam hal ini patogen, dan lingkungan. Beberapa penelitian mengungkapkan bahwa penurunan kualitas lingkungan perairan sangat berperan terhadap munculnya agent atau mikroorganisme pembawa pathogen terhadap karang. Sebagai contoh kenaikan dari nitrogen terlarut yang diikuti dengan penurunan kecerahan perairan dapat menyebabkan munculnya aspergillosis penyebab penyakit Black Band Disease [7]. Selain itu sedimentasi, polusi yang ditimbulkan oleh limbah domestik, sampah, sampai dengan air ballast yang masuk ke ekosistem terumbu karang berpotensi munculnya patogen penyebab penyakit karang.

Penulis memilih studi kasus mengenai penyakit pada terumbu karang karena di Indonesia kematian terumbu karang akibat hama dan penyakit masih belum menjadi perhatian khusus oleh para peneliti. Hal ini terbukti masih jarangnya penelitian yang mengungkapkan penyakit karang di perairan Indonesia. Beberapa penelitian yang pernah dilakukan diantaranya di Perairan Wakatobi Sulawesi Tenggara, Pulau Seribu DKI Jakarta, dan Pulau Panjang Jawa Tengah [8].

\section{B. Rumusan Masalah}

Bagaimana mengidentifikasi penyakit pada terumbu karang menggunakan metode Ripple Down Rules (RDR).

\section{Manfaat Penelitian}

Manfaat penelitian ini :

1. Sebagai acuan bagi masyarakat pembudidaya dan pengambil kebijakan untuk mengembangkan teknik diagnosa dan pengendalian penyakit pada terumbu karang yang tepat, efektif dan sistematis.

2. Sebagai acuan bagi petugas dinas kelautan baik daerah maupun pusat untuk menumbuhkan, mengembangkan dan meningkatkan kewaspadaan terhadap timbulnya penyakit pada terumbu karang di Indonesia.

\section{LANDASAN TEORI}

Sistem pakar adalah program komputer cerdas yang menggunakan pengetahuan dan prosedur-prosedur inferensi untuk menyelesaikan masalahmasalah yang membutuhkan seorang pakar dalam menemukan solusinya. Oleh sebab itu sistem pakar merupakan sebuah sistem yang mengemulasikan kemampuan membuat keputusan dari seorang pakar [9]. Arsitektur dalam sistem pakar memiliki variasi bentuk yang berbeda-beda, yang didasari oleh komponen-komponen yang berbeda juga. Tetapi pada umumnya komponen dasar yang pasti ada dalam sistem pakar antara lain, antarmuka pengguna, basis pengetahuan, akusisi pengetahuan dan mekanisme inferensi (inference engine). Mekanisme inferensi merupakan pusat dari sistem yang mengatur jalannya sistem pakar tersebut. Knowledge base merupakan tempat penyimpanan pengetahuan dari seorang pakar. Antarmuka pengguna merupakan sarana berkomunikasi antara pengguna dengan sistem. Akusisi pengetahuan digunakan untuk menyimpan pengetahuan dari seorang pakar ke dalam basis pengetahuan.

\section{A. Arsitektur Sistem Pakar}

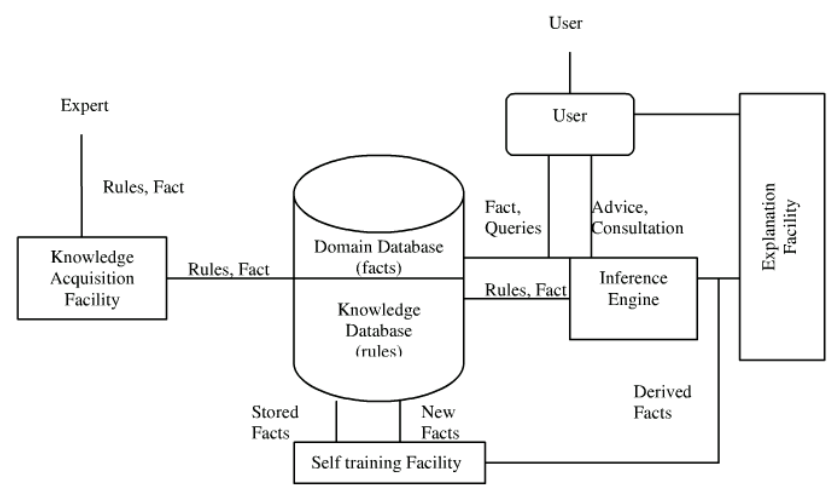

Gambar 1. Arsitektur sistem pakar

(James Martin \& Steve Osman, 1998, halaman 30)

Penjelasan setiap komponen yang terdapat pada Gambar 1 diatas sebagai berikut :

1) Akusisi Pengetahuan (Knowledge Acquisition Facility) : Dahulu pengaturan basis pengetahuan merupakan hal yang sulit dan menyita banyak waktu. Setiap fakta, aturan dan hubungan harus dimasukan ke dalam basis pengetahuan. Namun perangkat lunak yang ada sekarang memperbolehkan pakar untuk membuat dan mengubah basis pengetahuan melalui Knowledge Acquisition Facility (KAF). Knowledge Acquisition Facility $(K A F)$ ini bertujuan untuk menyediakan suatu dialog antara sistem pakar dengan seorang pakar untuk memperoleh pengetahuan, fakta dan aturan yang kemudian menempatkannya dalam knowledge base, sehingga membuat knowledge base menjadi lebih mudah dalam pengaturan dan pemeliharaan.

2) Basis Pengetahuan (Knowledge Base) : Komponen ini merupakan bagian yang terdapat dalam proses inferensi yang bertujuan untuk menyimpan informasi dan aturan-aturan penyelesaian suatu pokok bahasan masalah beserta atributnya. Knowledge Base mengandung pengetahuan untuk pemahaman, formulasi, dan penyelesaian masalah yang dapat berasal dari pakar, jurnal, majalah, dan sumber pengetahuan lain. Basis pengetahuan disusun atas dua elemen dasar yaitu fakta dan aturan. Fakta merupakan informasi tentang obyek dalam area permasalahan tertentu. Sedangkan aturan merupakan informasi tentang cara memperoleh fakta baru dari fakta yang telah diketahui. 3) Mekanisme Inferensi (Inference Engine) : Mesin inferensi merupakan perangkat lunak yang melakukan penalaran dengan menggunakan pengetahuan dari pakar untuk menganalisa data dan menghasilkan suatu kesimpulan atau hasil akhir yang direpresentasikan melalui user interface kepada pengguna. Komponen ini memiliki tugas utama untuk mengevaluasi kondisi (condition) dan memeriksa semua kondisi dalam sebuah 
aturan (rule) telah terpenuhi. Mekanisme inferensi yang terdapat dalam penelitian ini menggunakan algoritma forward chaining dalam penyusunan aturannya, dimana dari gejala-gejala yang diberikan oleh user dan kemudian mendapatkan hasil atau kesimpulan berupa penyakit yang dialami terumbu karang tersebut.

4) Fasilitas Penjelas (Explanation Facility) : Komponen tambahan ini akan meningkatkan kemampuan dari sistem pakar yaitu menggambarkan penalaran sistem kepada pengguna (user). Komponen tambahan ini juga berfungsi untuk menjelaskan kepada pengguna tentang bagaimana kesimpulan diambil oleh sistem pakar.

5) Antarmuka Pengguna (User Interface) : Komponen antarmuka pengguna ini digunakan untuk berkomunikasi antara sistem dengan pengguna (user). Komponen antarmuka pengguna berfungsi menerima informasi yang diberikan oleh pengguna lalu mengubahnya ke dalam bentuk yang dapat diterima oleh sistem. Selain itu komponen antarmuka pengguna ini juga berfungsi menerima informasi dari sistem lalu menyajikannya ke dalam bentuk yang dapat dimengerti oleh pengguna.

6) Memori Kerja (Working Memory) : Komponen ini menyimpan sementara setiap fakta jawaban dari pengguna yang kemudian digunakan oleh mesin inferensi untuk membandingkan fakta tersebut dengan aturan yang ada dalam basis aturan dengan menggunakan metode forward chaining yang nantinya menghasilkan jawaban berupa penyakit yang dicari oleh user.

7) Sistem Pembelajaran (Self Training Facility) : Komponen ini berfungsi melakukan pembelajaran secara mandiri sehingga dapat mengolah aturan (rule) dan fakta (fact) dengan benar. Komponen ini merupakan fasilitas untuk mengatur posisi dari pengetahuan yang didapat dari pakar ke dalam basis pengetahuan (knowledge base), dimana pengetahuan tersebut secara mandiri dikonversikan oleh sistem ke dalam bahasa yang dapat dibaca oleh komputer. Metode Ripple Down Rules (RDR) merupakan bagian dari self training facility dimana metode ini akan melakukan pembelajaran secara mandiri terhadap suatu fakta yang diberikan oleh pengguna, yang mengubahnya menjadi bentuk aturan-aturan agar dapat dilakukan proses inferensi berdasarkan aturan tersebut.

\section{B. Ripple Down Rules (RDR)}

Menurut penelitian yang dilakukan oleh Campton dan Peters [11] dijelaskan bahwa ketika seorang pakar mendapat pertanyaan mengenai bagaimana mencapai sebuah kesimpulan dari suatu pengetahuan, maka pakar akan

memberikan pernyataan bahwa kesimpulan yang dia berikan adalah benar. Meskipun pakar dalam memberikan kesimpulan belum diketahui secara pasti tentang kebenarannya. Hal ini mengakibatkan sistem pakar menjadi tidak valid dalam melakukan akusisi pengetahuan. Oleh sebab itu, diperlukan metode Ripple Down Rules (RDR) untuk menyelesaikan permasalahan tersebut.

Terdapat dua fitur utama Ripple Down Rules (RDR) untuk penambahan pengetahuan dalam sistem pakar [11] :

1. Jika pengetahuan yang terdapat dalam basis data tidak benar, maka sebuah aturan pembenaran yang telah dibuat digunakan untuk menggantikan aturan yang salah yang membuat aturan pembenaran tersebut hanya dapat dijalankan pada tingkatan yang sama dengan aturan yang salah. Lalu ketika aturan utama (aturan yang salah) dikerjakan, maka aturan pembenaran yang akan dipilih untuk dikerjakan daripada aturan utama tersebut.

2. Pakar hanya diperbolehkan menambah ataupun memperbaiki aturan yang berada dalam satu susunan aturan. Dimana jika memerlukan fakta dari susunan aturan yang lain maka susunan aturan baru yang dibentuk haruslah memiliki perbedaan dengan susunan aturan lain agar tidak terjadi tabrakan pengetahuan antar susunan aturan yang ada.

Pengimplementasian Ripple Down Rules (RDR) dalam sistem dilakukan ketika sistem tersebut sedang dijalankan. Prosesnya dimulai dengan basis data kosong yang dibangun secara bertahap dari waktu ke waktu dalam suatu kasus pemrosesan. Tugas seorang pakar disini adalah memonitor output dan secara bertahap menambahkan aturan sampai mencapai suatu kesimpulan yang dianggap benar. Sebagai sistem yang berkembang, pengetahuan diberikan oleh pakar pastinya terdapat pengetahuan yang benar, salah atau hilang. Jika salah atau hilang maka pakar akan menambahkan pengetahuan yang digunakan untuk memperbaiki pengetahuan yang salah tersebut. Lalu sistem akan mengatur ulang setiap aturan yang ditambah ataupun diubah oleh pakar dan juga memasukan aturan tersebut ke dalam basis aturan sebagai penyempurnaan dari aturan yang terbentuk dari pengetahuan yang salah. Dimana aturan ini hanya ditambahkan pada akhir dari aturan sebelumnya dan hanya dievaluasi setelah aturan sebelumnya telah dievaluasi [11].

Menurut penelitian yang dilakukan oleh Jursic dan Morzetic [12] metode Ripple Down Rules (RDR) digunakan untuk akuisisi pengetahuan tambahan dan pemeliharaan sistem berbasis aturan. Jika dibandingkan dengan standar jika-maka dari suatu aturan klasifikasi, Ripple Down Rules $(R D R)$ memiliki bentuk yang sama yaitu IF-THEN-ELSE. Konsep IF-THEN-ELSE terjadi ketika aturan yang paling umum dibangun pertama mengalami pembenaran oleh pakar, maka suatu aturan pembenaran baru akan ditambahkan sebagai suatu proses membangun aturan baru yang mengubah aturan utama yang salah. Ripple Down Rules $(R D R)$ membentuk struktur susunan aturan dimana aturan utama dijalankan saat aturan tersebut tidak mengalami pembenaran namun jika terjadi pembenaran aturan oleh pakar maka akan dilakukan pengubahan bentuk susunan aturan dalam sistem pakar ini [11].

Ripple Down Rules (RDR) pada awalnya adalah teknik akuisi pengetahuan secara umum dimana area aplikasi yang dimaksud di sini adalah kemampuan untuk menambahkan komentar klinis atau interpretasi laporan laboratorium untuk membantu dokter dalam memberi rujukan. Artinya, dokter yang memerintahkan tes darah patologi kimia, menerima 
tidak hanya hasil laboratorium tetapi saran dari ahli patologi terhadap interpretasi hasil pengujian, pengujian lebih lanjut yang mungkin diperlukan dan sebagainya. Banyak laporan patologi berisi semacam komentar sederhana dan seadanya; tujuan dari penggunaan Knowledge Base System (KBS) adalah untuk memberikan komentar jauh lebih rinci yang diberikan oleh ahli patologi di klinik pengelolaan pasien tertentu.

Keuntungan dari area ini untuk sistem pakar atau teknologi Artificial Intelligence (AI) lainnya adalah bahwa tidak ada permintaan atau harapan terhadap dokter untuk menerima laporan. Dokter tidak harus berinteraksi dengan sistem, atau mengubah cara operasionalnya. Dokter bisa memilih untuk mengagendakan tes diagnostik untuk pasien, melihat laporan, termasuk memberikan komentar interpretatif.

Tentu saja, kualitas komentar akan menjadi penting terutama apakah dokter memperhatikan komentar tersebut, tetapi kualitas komentar murni tergantung pada tingkat keahlian dari sistem, bukan pada isu-isu integrasi ke dalam alur kerja klinis. Menurut laporan [13] mengenai system pakar yang rutin digunakan untuk mencatat bahwa tiga dari empat sistem medis pertama rutin digunakan untuk menyediakan interpretasi klinis dari hasil tes diagnostik.

Ripple Down Rules (RDR) awalnya dikembangkan untuk menangani masalah pemeliharaan salah satu sistem pakar medis pertama. Mereka pertama kali diuji dalam bidang kedokteran di sistem PEIRS. Namun, dalam studi ini ada domain seorang ahli tunggal yang sangat erat terlibat dalam pengembangan dan penggunaan sistem, sehingga selalu menjadi pertanyaan apakah teknik ini akan berguna di tangan yang berbeda. Telah dilakukan berbagai evaluasi untuk jenis masalah yang berbeda, tapi ini semua dilakukan dalam konteks penelitian.

Pada perkembangannya Ripple Down Rules (RDR) merupakan strategi dalam mengembangkan sistem secara bertahap dimana sistem tersebut sudah digunakan. Saat sistem tidak memberikan respon yang benar maka perubahan perlu dilakukan tanpa mempengaruhi kompetensi sistem. Perubahan harus dapat dilakukan dengan mudah dan cepat serta kesulitan dalam melakukan perubahan tidak boleh meningkat meskipun sistem berkembang. Berbagai sistem Ripple Down Rules (RDR) komersial telah dikembangkan untuk berbagai macam aplikasi. Riset telah membuktikan penggunaan Ripple Down Rules (RDR) di berbagai aplikasi seperti : pengklasifikasian masalah, konfigurasi dan pencocokan parameter, pengolahan teks, pengolahan citra, pencarian heuristik dan pencocokan algoritma genetika.

\section{Forward Chaining}

Metode yang digunakan dalam penelitian ini adalah penalaran maju (forward chaining). Penalaran maju (forward chaining) adalah metode inferensi yang memulai dengan menyusun fakta yang diketahui dan fakta-fakta baru dengan menggunakan aturan yang memiliki premis sesuai dengan fakta yang diketahui, dan proses ini berlanjut sampai sebuah kesimpulan tercapai atau sampai tidak ada aturan yang sesuai dengan fakta yang diketahui [1].

Aturan-aturan yang ada dalam metode ini diuji satu demi satu dalam suatu urutan tertentu. Saat tiap aturan diuji, sistem pakar akan mengevaluasi apakah kondisinya benar atau salah. Jika kondisi benar, maka aturan itu disimpan kemudian aturan berikutnya diuji. Namun sebaliknya jika kondisi salah, aturan tidak disimpan. Proses ini akan berulang sampai seluruh aturan yang ada telah teruji dengan berbagai kondisi. Hal ini bisa kita lihat di Gambar 2.

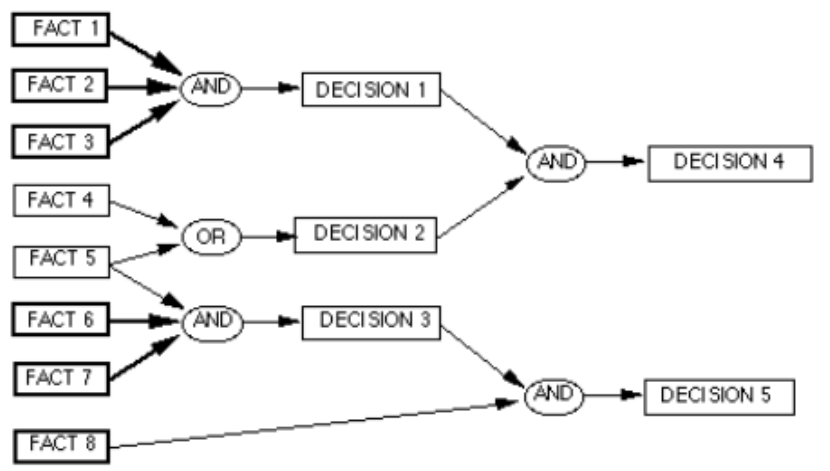

Gambar 2. Forward Chaining

(Bratko ed.4, bab 15, hal 343)

Jika ditemukan identifikasi suatu kasus tidak benar, maka pakar hanya perlu memasukkan fakta yang benar untuk diletakkan pada bagian fakta yang salah tadi, lalu sistem akan membentuk aturan yang baru berdasarkan fakta yang diberikan oleh pakar dan juga aturan tersebut akan ditandai sebagai updating rule. Updating rule adalah penambahan suatu aturan pengecualian tanpa mengubah susunan dan kualitas dari rule-rule yang telah ada sebelumnya. Jika suatu rule telah mengalami updating rule, maka user akan melihat tampilan terbaru dari kasus tersebut. Contoh pengimplementasian metode Ripple Down Rules $(R D R)$ pada kasus ini bisa kita lihat pada Gambar 3 di bawah :

Aturan awal yang terbentuk dalam system

1. IF bekas luka/goresan terlihat jelas

2. AND rusaknya rangka karang

3. AND bekas gigitan berwarna putih

4. AND bekas luka ditumbuhi alga

5. AND beberapa luka bisa sembuh

6. AND ditemukan ikan predator di area survey

7. THEN penyakit adalah Fish Bites

Gambar 3. Aturan awal dalam implementasi Ripple Down Rules (RDR)

Lalu pakar ingin memperbaiki gejala yang ada dalam sistem dan menggantinya menjadi gejala baru, seperti dalam kasus ini pakar ingin mengubah gejala bekas gigitan berwarna putih menjadi bekas gigitan berwarna coklat. Pada Gambar 4 berikut ini pengimplementasian pengubahan gejala yang dimasukan oleh pakar :

1. Sistem akan menunjukan semua yang berhubungan dengan penyakit yang akan diubah :

Kode penyakit : P001

Nama penyakit : Fish Bites

Kode Gejala : G001

Nama Gejala : bekas luka terlihat jelas

Kode Gejala : G002

Nama Gejala : rusaknya rangka karang

Kode Gejala : G003

Nama Gejala : bekas gigitan berwarna putih 
Kode Gejala : G004

Nama Gejala : bekas luka ditumbuhi algae

Kode Gejala : G005

Nama Gejala : beberapa luka bisa sembuh

Kode Gejala : G006

Nama Gejala : ditemukan ikan predator di area survey

2. Setelah itu sistem menanyakan gejala lama apa yang akan diubah di dalam sistem ini :

Kode Penyakit : P001

Penyakit : Fish Bites

Kode Gejala : bekas gigitan berwarna putih

3. Lalu sistem akan meminta aturan baru yang akan ditambahkan ke dalam Sistem Pakar :

Gejala Baru : bekas gigitan berwarna coklat

4. Setelah itu sistem akan melakukan pelacakan basis aturan yang berhubungan dengan Fish Bites dan bekas gigitan berwarna putih dan mengubah gejala lama tersebut menjadi bekas gigitan berwarna coklat.

Gambar 4. Impementasi pengubahan gejala

Setelah itu sistem menyusun bentuk aturan yang baru seperti pada Gambar 5 di bawah :

1. IF bekas luka/goresan terlihat jelas

2. AND rusaknya rangka karang

3. AND bekas gigitan berwarna coklat

4. AND bekas luka ditumbuhi alga

5. AND beberapa luka bisa sembuh

6. AND ditemukan ikan predator di area survey

7. THEN penyakit adalah Fish Bites

Gambar 5. Impementasi aturan baru

\section{Bahan dan Alat}

Bahan yang digunakan untuk pembuatan sistem pakar ini adalah beberapa buku yang menjelaskan tentang penyakit ikan air laut, serta pengetahuan yang diperoleh dari materi presentasi yang dipublikasikan oleh Bapak Edy Setyawan dan Ibu Estradivari pakar di bidang penyakit terumbu karang dari Terangi Foundation pada tahun 2016 [15]. Alat yang digunakan dalam penelitian ini adalah sebuah komputer dan beberapa perangkat lunak pendukung seperti : Microsoft Word, Editplus, Bootstrap, WAMP server, PHP dan MySQL.

\section{E. Use Case Diagram, Struktur dan Relasi Tabel}

Dalam mendukung perancangan sistem pakar ini diperlukan suatu gambaran umum interaksi antara elemenelemen yang terlibat dalam sistem. Gambaran umum ini berguna untuk mengetahui fungsionalitas yang diharapkan dari suatu sistem. Adapun untuk mendapatkan gambaran umum mengenai interaksi antar elemen dalam sistem serta menggambarkan fungsionalitas sistem secara jelas, maka digunakan alat bantu pemodelan berupa use case diagram. Diagram ini terdiri atas empat komponen utama yaitu (1) boundary, yang menggambarkan ruang lingkup sistem; (2) actor, yang menggambarkan individu-individu yang berinteraksi dalam sistem sesuai dengan perannya; (3) use case, menggambarkan apa yang dikerjakan oleh sistem; (4) relationship, menggambarkan relasi yang terjadi antara actor dan use case. Rancangan use case diagram untuk sistem pakar ini dapat dilihat pada Gambar 6.

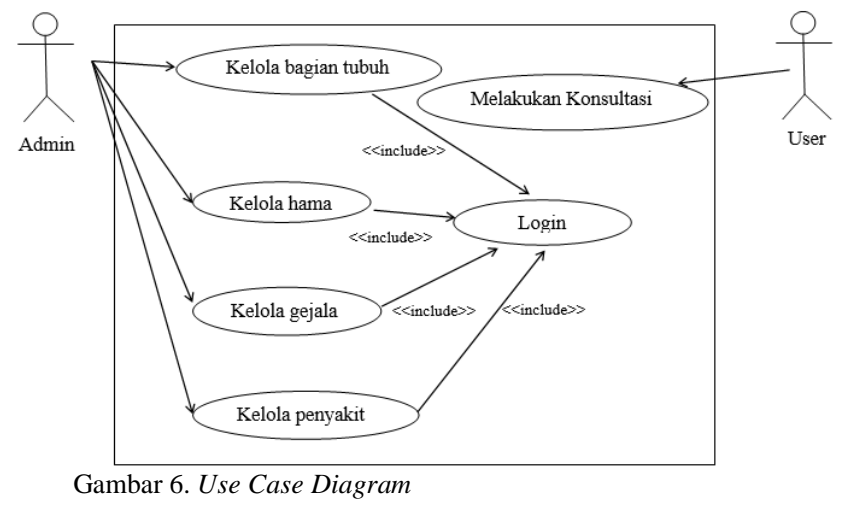

Adapun struktur tabel dan relasi antar tabel yang digunakan dalam perancangan sistem pakar seperti Tabel 1 sampai Tabel 8 :

Tabel 1. Tabel aturan_penyakit.sql

\begin{tabular}{|c|c|c|}
\hline Nama Kolom & Tipe Data & Keterangan \\
\hline id_rule & $\operatorname{int}(5)$ & $\begin{array}{l}\text { identitas dari aturan } \\
\text { gejala yang dibuat }\end{array}$ \\
\hline aturan_gejala & varchar(500) & $\begin{array}{l}\text { aturan dari gejala } \\
\text { suatu penyakit }\end{array}$ \\
\hline kode_hama & $\operatorname{varchar}(5)$ & $\begin{array}{l}\text { kode hama suatu } \\
\text { penyakit }\end{array}$ \\
\hline kode_jenis & $\operatorname{varchar}(5)$ & $\begin{array}{l}\text { jenis hama suatu } \\
\text { penyakit }\end{array}$ \\
\hline kode_penyakit & $\operatorname{varchar}(5)$ & $\begin{array}{l}\text { kode dari penyakit } \\
\text { tertentu }\end{array}$ \\
\hline urutan & $\operatorname{int}(6)$ & $\begin{array}{cc}\text { nomor urut dari } \\
\text { suatu aturan gejala }\end{array}$ \\
\hline urutan2 & $\operatorname{int}(6)$ & $\begin{array}{l}\text { nomor urut prioritas } \\
\text { kedua dari suatu aturan } \\
\text { gejala }\end{array}$ \\
\hline sama & $\operatorname{int}(6)$ & $\begin{array}{l}\text { menandakan jumlah } \\
\text { gejala yang sama dari } \\
\text { aturan gejala }\end{array}$ \\
\hline
\end{tabular}

\begin{tabular}{|c|c|c|}
\multicolumn{2}{c}{ Tabel 2. Tabel bagian.sql } \\
\hline $\begin{array}{c}\text { Nama } \\
\text { Kolom }\end{array}$ & Tipe Data & Keterangan \\
\hline kode_bagian & varchar(5) & $\begin{array}{c}\text { kode bagian yang } \\
\text { mengalami gejala }\end{array}$ \\
\hline bagian_gejala & varchar(5) & $\begin{array}{c}\text { nama bagian yang } \\
\text { mengalami gejala }\end{array}$ \\
\hline pertanyaan & varchar(200) & $\begin{array}{c}\text { daftar pertanyaan } \\
\text { yang di ajukan }\end{array}$ \\
\hline
\end{tabular}

\begin{tabular}{|c|c|c|}
\multicolumn{2}{c}{} & Tabel 3. Tabel gejala.sql \\
\hline $\begin{array}{c}\text { Nama } \\
\text { Kolom }\end{array}$ & Tipe Data & Keterangan \\
\hline kode_gejala & varchar(5) & $\begin{array}{c}\text { kode gejala dari } \\
\text { suatu penyakit }\end{array}$ \\
\hline kode_bagian & varchar(5) & $\begin{array}{c}\text { kode bagian yang } \\
\text { mengalami gejala }\end{array}$ \\
\hline gejala & varchar(200) & $\begin{array}{c}\text { gejala yang di alami } \\
\text { oleh terumbu karang }\end{array}$ \\
\hline
\end{tabular}

Tabel 4. Tabel hama.sql

\begin{tabular}{|c|c|c|}
\hline $\begin{array}{c}\text { Nama } \\
\text { Kolom }\end{array}$ & Tipe Data & Keterangan \\
\hline kode_jenis & varchar(5) & $\begin{array}{c}\text { kode jenis hama dari } \\
\text { suatu penyakit }\end{array}$ \\
\hline jenis_hama & varchar(50) & $\begin{array}{c}\text { jenis hama dari suatu } \\
\text { penyakit }\end{array}$ \\
\hline
\end{tabular}


Tabel 5. Tabel hitung_urutan.sql

\begin{tabular}{|c|c|c|}
\hline Nama Kolom & \multicolumn{1}{|c|}{ Tipe } & \multicolumn{1}{|c|}{ Keterangan } \\
\hline urutan & $\operatorname{int}(5)$ & $\begin{array}{l}\text { nomor urut dari aturan } \\
\text { gejala }\end{array}$ \\
\hline jumlah_urutan & $\operatorname{int}(5)$ & $\begin{array}{l}\text { jumlah urutan dengan } \\
\text { nomor urut tertentu dari aturan } \\
\text { gejala }\end{array}$ \\
\hline
\end{tabular}

Tabel 6. Tabel nama_hama.sql

\begin{tabular}{|c|c|c|}
\hline $\begin{array}{c}\text { Nama } \\
\text { Kolom }\end{array}$ & Tipe Data & Keterangan \\
\hline kode_hama & varchar(5) & $\begin{array}{c}\text { kode hama dari suatu } \\
\text { penyakit }\end{array}$ \\
\hline nama_hama & varchar(70) & $\begin{array}{c}\text { nama hama dari suatu } \\
\text { penyakit }\end{array}$ \\
\hline
\end{tabular}

Tabel 7. Tabel penyakit.sql

\begin{tabular}{|c|c|c|}
\hline Nama Kolom & Tipe Data & \multicolumn{1}{|c|}{ Keterangan } \\
\hline kode_penyakit & varchar(5) & $\begin{array}{c}\text { kode dari masing- } \\
\text { masing penyakit }\end{array}$ \\
\hline penyakit & varchar(100) & $\begin{array}{c}\text { nama dari masing- } \\
\text { masing penyakit }\end{array}$ \\
\hline gambar & varchar(50) & $\begin{array}{l}\text { contoh gambar dari } \\
\text { terumbu karang yang } \\
\text { terkena penyakit }\end{array}$ \\
\hline
\end{tabular}

Tabel 8. Tabel user.sql

\begin{tabular}{|c|c|c|}
\hline $\begin{array}{c}\text { Nama } \\
\text { Kolom }\end{array}$ & Tipe Data & Keterangan \\
\hline id_user & $\operatorname{int}(3)$ & $\begin{array}{c}\text { id dari user yang bisa login } \\
\text { ke sistem }\end{array}$ \\
\hline username & varchar(50) & $\begin{array}{c}\text { username dari user yang } \\
\text { bisa login ke sistem }\end{array}$ \\
\hline password & varchar(50) & $\begin{array}{c}\text { password dari user yang } \\
\text { bisa login ke sistem }\end{array}$ \\
\hline
\end{tabular}

Adapun relasi antar tabel untuk pembuatan prototipe sistem pakar adalah seperti yang terlihat pada Gambar 7.

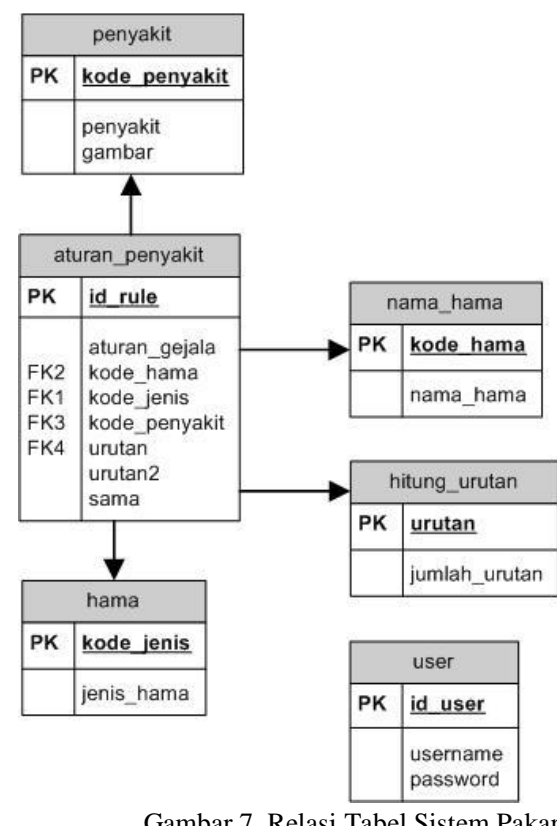

\section{F. Diagram Alur Proses Konsultasi Pada Sistem}

Diagram alur pada Gambar 8 menjelaskan tentang alur dari cara kerja sistem yang akan dibuat. Ketika pengguna atau pakar memilih menu konsultasi. Sistem akan mengajukan pertanyaan- pertanyaan berbeda yang akan ditampilkan satu persatu sesuai dengan basis aturan yang ada. Jawaban dari pengguna akan dimasukan ke dalam working memory lalu sistem akan melakukan pengecekan jawaban dengan aturan yang ada dalam basis aturan. Jika aturan dengan jawaban pada working memory sesuai, maka akan ditampilkan pertanyaan selanjutnya sesuai dengan basis aturan yang ada. Ketika pertanyaan telah selesai diajukan kepada pengguna, maka sistem akan menampilkan hasil sesuai dengan jawaban yang dimasukan oleh pengguna, namun jika tidak ditemukan aturan yang sesuai maka akan ditampilkan default output pada user.

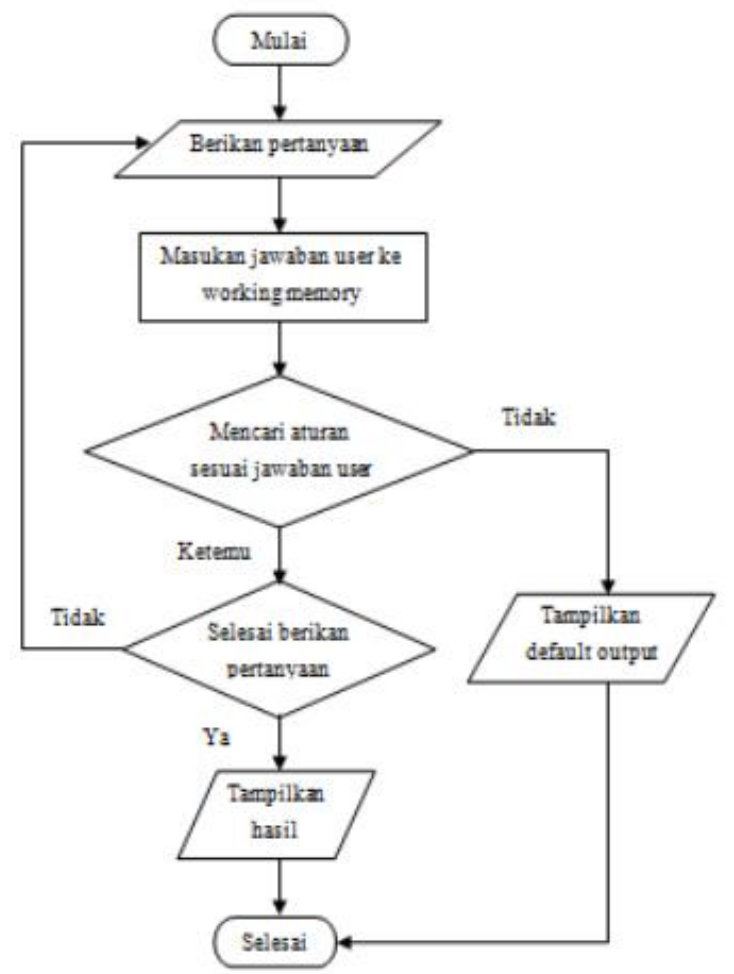

Gambar 8. Diagram Alur Proses Konsultasi pada Sistem

G. Diagram alur penerapan metode Ripple Down Rules (RDR)

Diagram alur ini menjelaskan alur dari cara kerja sistem dalam penerapan metode Ripple Down Rules (RDR) yaitu memperbaiki dan menghapus fakta dan aturan yang ada dalam basis data dan juga pengetahuan pada pertanyaan yang diajukan kepada pengguna. 


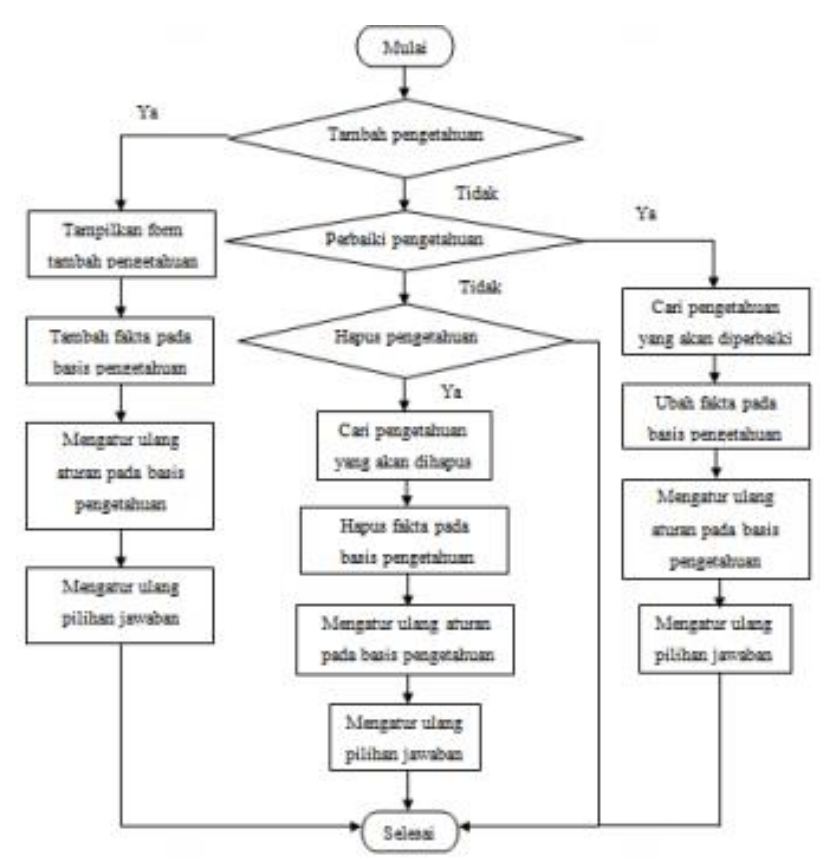

Gambar 9. Diagram Alur Ripple Down Rules (RDR)

Gambar 9 menjelaskan tentang kerja metode Ripple Down Rules $(R D R)$ dalam sistem pakar ini. Ketika pakar telah berhasil melakukan login ke dalam sistem maka pakar akan diarahkan ke dalam menu konsultasi khusus untuk pakar. Menu ini memiliki beberapa tombol yang dapat digunakan oleh pakar untuk menuju menu berikutnya. Metode Ripple Down Rules (RDR) terjadi ketika pakar memilih menu tambah, perbaiki ataupun menghapus pengetahuan, dimana jika pakar memilih menu tambah maka sistem akan menampilkan form untuk menambah pengetahuan lalu menambahkan pengetahuan tersebut ke dalam sistem. Lalu jika pakar memilih menu perbaiki ataupun hapus pengetahuan, sistem akan mencari pengetahuan lama yang ingin diubah dan mengubah pengetahuan tersebut menjadi pengetahuan baru yang dimasukan oleh pakar. Setelah penambahan, perbaiki ataupun penghapusan pengetahuan telah selesai dilakukan oleh pakar. Sistem akan membangun suatu aturan baru berdasarkan pengetahuan yang dimasukan oleh pakar lalu mengubahnya menjadi bentuk aturan-aturan baru dan memasukannya ke dalam basis aturan. Lalu sistem akan melakukan pengaturan ulang aturan-aturan yang ada dalam basis aturan.

\section{H. Perancangan Basis Pengetahuan}

Basis pengetahuan yang terdapat dalam sistem pakar ini menyimpan fakta yang berhubungan dengan penyakit terumbu karang dan gejalanya yang digunakan untuk mencari sebuah kesimpulan. Fakta tersebut didapat dari hasil wawancara dengan pakar dan sumber lain seperti buku, jurnal dan artikel. Selanjutnya diterjemahkan ke dalam bahasa komputer dan disimpan ke dalam basis data. Fakta yang ada dalam sistem pakar ini terdiri dari 5 kategori yaitu bagian gejala, gejala, nama hama penyakit, jenis hama penyakit, dan nama penyakit yang bisa kita lihat pada Tabel 9, 10, 11, 12 dan 13. Selanjutnya fakta tersebut digunakan untuk membangun pohon keputusan dan menyusun basis aturan untuk mendapatkan solusi yang dibutuhkan oleh sistem.

Tabel 9. Kode dan Bagian Gejala

\begin{tabular}{|c|c|}
\hline Kode_B & Bagian_Gejala \\
\hline B001 & rangka \\
\hline B002 & jaringan \\
\hline B003 & koloni \\
\hline B004 & cabang karang \\
\hline B005 & permukaan \\
\hline B006 & corallite \\
\hline B007 & luka \\
\hline B008 & zooxanthellae \\
\hline B009 & coenesteum \\
\hline B010 & polip \\
\hline B011 & dasar karang \\
\hline
\end{tabular}

Tabel 10. Kode dan Gejala

\begin{tabular}{|c|c|c|}
\hline $\begin{array}{ll} & \text { Kode_ } \\
\text { G } & \\
\end{array}$ & $\begin{array}{ll} & \text { Kode_ } \\
\text { B } & \\
\end{array}$ & Gejala \\
\hline G001 & B001 & bekas luka terlihat jelas \\
\hline G002 & B001 & rusaknya rangka \\
\hline G003 & B001 & bekas gigitan berwarna putih \\
\hline G004 & B001 & bekas luka ditumbuhi algae \\
\hline G005 & B001 & beberapa luka bisa sembuh \\
\hline G006 & B001 & ditemukan ikan predator di area \\
\hline G007 & B002 & hilangnya jaringan \\
\hline G008 & B001 & rangka berwarna putih \\
\hline G009 & B002 & ditemukan CoT di area \\
\hline G010 & B002 & meliputi area yg luas \\
\hline G011 & B003 & pemangsaan di tepi koloni \\
\hline G012 & B003 & bekas pemangsaan di koloni \\
\hline G013 & B004 & ditemukan siput berwarna putih \\
\hline G014 & B004 & $\begin{array}{l}\text { pemagsaan dari dasar hingga } \\
\text { ujung }\end{array}$ \\
\hline G015 & B004 & bekas pemangsaan lebih kecil \\
\hline G016 & B004 & $\begin{array}{l}\text { bekas pemangsaan dg batas tidak } \\
\text { teratur }\end{array}$ \\
\hline G017 & B003 & $\begin{array}{l}\text { ditemukan drupella di dasar } \\
\text { koloni }\end{array}$ \\
\hline G018 & B005 & $\begin{array}{l}\text { ditemukan sedimen di permukaan } \\
\text { karang }\end{array}$ \\
\hline G019 & B002 & $\begin{array}{l}\text { pertumbuhan algae di jaringan } \\
\text { hidup }\end{array}$ \\
\hline G020 & B002 & $\begin{array}{l}\text { ditemukan band } \text { berbentuk } \\
\text { annular/linear }\end{array}$ \\
\hline G021 & B002 & $\begin{array}{ll}\text { ditemukan band berwarna } \\
\text { hitam/coklat }\end{array}$ \\
\hline G022 & B001 & ditemukan cyanobacteria \\
\hline G023 & B007 & band menyebar keluar dari luka \\
\hline G024 & B007 & ditemukan band di karang masif \\
\hline G025 & B001 & rangka kosong ditumbuhi algae \\
\hline G026 & B007 & batas luka discrete atau diffuse \\
\hline G027 & B007 & batas luka tidak berpigmen \\
\hline G028 & B002 & laju kehilangan jaringan cepat \\
\hline
\end{tabular}




\begin{tabular}{|c|c|c|}
\hline G Kode_ & B Kode $_{-}$ & Gejala \\
\hline G029 & B007 & $\begin{array}{l}\text { luka dekat penyakit berwarna } \\
\text { putih }\end{array}$ \\
\hline G030 & B007 & $\begin{array}{l}\text { luka bertahap berubah warna } \\
\text { coklat }\end{array}$ \\
\hline G031 & B007 & garis tepi di luka berbentuk garis \\
\hline G032 & B007 & $\begin{array}{r}\text { luka berbentuk focal dan } \\
\text { multifocal }\end{array}$ \\
\hline G033 & B007 & $\begin{array}{lll}\begin{array}{c}\text { luka dengan } \\
\text { annular/linear }\end{array} & \text { garis tepi } \\
\end{array}$ \\
\hline G034 & B007 & $\begin{array}{lll}\text { luka berbatasan dg jaringan } \\
\text { karang sehat }\end{array}$ \\
\hline G035 & B007 & $\begin{array}{l}\text { perkembangan luka dari } \mathrm{mm} \mathrm{ke} \\
\mathrm{cm} \text { per bulan }\end{array}$ \\
\hline G036 & B002 & $\begin{array}{c}\text { pita paling depan berwarna } \\
\text { kuning pucat }\end{array}$ \\
\hline G037 & B002 & $\begin{array}{l}\text { jaringan terinfeksi berwarna lebih } \\
\text { gelap }\end{array}$ \\
\hline G038 & B002 & $\begin{array}{c}\text { pola luka } \\
\text { multifocal/diffuse }\end{array}$ \\
\hline G039 & B002 & $\begin{array}{ccc}\begin{array}{c}\text { warna } \\
\text { pink/ungu/biru }\end{array} & \text { jaringan jadi } \\
\end{array}$ \\
\hline G040 & B002 & dinding corallite menebal \\
\hline G041 & B002 & pigmentasi berbentuk garis \\
\hline G042 & B002 & pigmentasi berbentuk titik \\
\hline G043 & B002 & pigmentasi berbentuk benjolan \\
\hline G044 & B002 & $\begin{array}{lll}\text { pigmentasi } & \text { berbentuk tidak } \\
\text { teratur } & & \\
\end{array}$ \\
\hline G045 & B001 & respon terhadap biota pengebor \\
\hline G046 & B001 & respon terhadap kompetisi \\
\hline G047 & B001 & respon terhadap serangan alga \\
\hline G048 & B002 & jaringan membengkak \\
\hline G049 & B002 & $\begin{array}{l}\text { jaringan berwarna pink hingga } \\
\text { putih }\end{array}$ \\
\hline G050 & B002 & ditemukan trematode parasit \\
\hline G051 & B001 & karang masih hidup \\
\hline G052 & B010 & polip masih terlihat \\
\hline G053 & B002 & $\begin{array}{l}\text { adanya gradien jaringan sehat dg } \\
\text { sakit }\end{array}$ \\
\hline G054 & B008 & $\begin{array}{llll}\text { hilangnya alga simbion pada } \\
\text { karang }\end{array}$ \\
\hline G055 & B008 & $\begin{array}{l}\text { tekanan terhadap lingkungan } \\
(\mathrm{suhu})\end{array}$ \\
\hline G056 & $\mathrm{B} 002$ & area jaringan berwarna putih \\
\hline G057 & B002 & jaringan masih ada \\
\hline G058 & B002 & tidak ada pigmentasi jaringan \\
\hline G059 & B002 & $\begin{array}{l}\text { ditemukan garis dengan batas yg } \\
\text { jelas }\end{array}$ \\
\hline G060 & B002 & $\begin{array}{ccc}\begin{array}{c}\text { tingkat } \\
\text { bervariasi }\end{array} & \text { pemutihan } & \text { karang } \\
\end{array}$ \\
\hline G061 & B001 & $\begin{array}{rrr}\begin{array}{r}\text { deformasi } \\
\text { focal/multifocal }\end{array} & \text { rangka } & \text { berbentuk } \\
\end{array}$ \\
\hline G062 & B001 & ditemukan invertebrata \\
\hline G063 & B001 & deformasi rangka tidak beraturan \\
\hline G064 & B001 & coenesteum menebal \\
\hline G065 & B007 & $\begin{array}{l}\text { luka berbentuk circular hingga } \\
\text { difuse }\end{array}$ \\
\hline G066 & B002 & berwarna lebih muda \\
\hline G067 & B002 & tidak berwarna sama sekali \\
\hline G068 & B002 & $\begin{array}{l}\text { tidak ada jaringan antara sehat } \\
\text { dan sakit }\end{array}$ \\
\hline G069 & B001 & rangka utuh dan terbuka \\
\hline
\end{tabular}

Tabel 11. Kode dan Nama Hama

\begin{tabular}{|l|l|}
\hline \multicolumn{1}{|c|}{ Kode_Ham } & Nama_Hama \\
\hline NH001 & Ikan Kakaktua, Buntal, Betok \\
\hline NH002 & Bintang Laut Crown of Thorns \\
\hline NH003 & Siput Drupella \\
\hline NH004 & Algae \\
\hline NH005 & Cyanobacteria \\
\hline NH006 & Nudibranch \\
\hline NH007 & Flatworm \\
\hline NH008 & Invertebrata \\
\hline NH009 & Sedimen \\
\hline NH010 & Phormidium corallyticum \\
\hline NH011 & Mikroba Pathogen \\
\hline NH012 & Virulence \\
\hline NH013 & Suhu Meningkat \\
\hline NH014 & Tidak Diketahui \\
\hline
\end{tabular}

Tabel 12. Kode dan Jenis Hama

\begin{tabular}{|l|l|}
\hline \multicolumn{1}{|c|}{ Sode_Jeni } & Jenis_Hama \\
\hline H001 & Ikan \\
\hline H002 & Siput \\
\hline H003 & Algae \\
\hline H004 & Bintang Laut \\
\hline H005 & Bakteri \\
\hline H006 & Cacing \\
\hline H007 & Invertebrata \\
\hline H008 & Sedimen \\
\hline H009 & Mikroba \\
\hline H010 & Lingkungan \\
\hline H011 & Tidak Diketahui \\
\hline
\end{tabular}

Tabel 13. Kode dan Nama Penyakit

\begin{tabular}{|l|l|}
\hline Kode_P & Penyakit \\
\hline P001 & Fish Bites \\
\hline P002 & CoT Predation \\
\hline P003 & Drupella Predation \\
\hline P004 & Sedimentation Damage \\
\hline P005 & Algae Overgrowth \\
\hline P006 & Black Band Disease \\
\hline P007 & White Syndromes \\
\hline P008 & Yellow Band Disease \\
\hline P009 & Pigmentation Response \\
\hline P010 & Trematodiasis \\
\hline P011 & Bleaching \\
\hline P012 & Unusual Bleaching Pattern \\
\hline P013 & Galls \\
\hline P014 & Growth Anomalies of Unknown Cause \\
\hline
\end{tabular}

\section{IMPLEMENTASI}

\section{A. Halaman Index}

Halaman index merupakan halaman pertama yang tampil ke user saat mengakses sistem pakar ini. Tampilannya bisa kita lihat pada Gambar 10 di bawah. Di halaman ini 
terdapat informasi rekapitulasi jumlah Penyakit Teridentifikasi, Gejala Teridentifikasi, Hama Terindentifikasi dan Bagian Teridentifikasi.

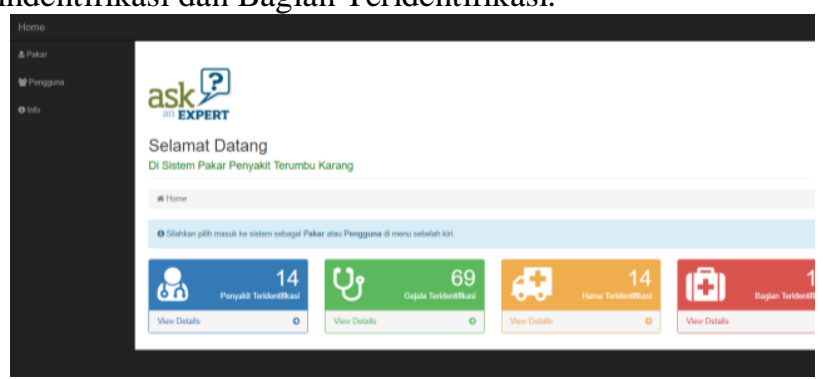

Gambar 10. Halaman Index

\section{B. Halaman Detil Penyakit}

Halaman detil penyakit merupakan halaman yang berisi gambar, nama penyakit, nama hama, jenis hama dan gejala suatu penyakit. Tampilannya bisa kita lihat pada Gambar 11 di bawah.

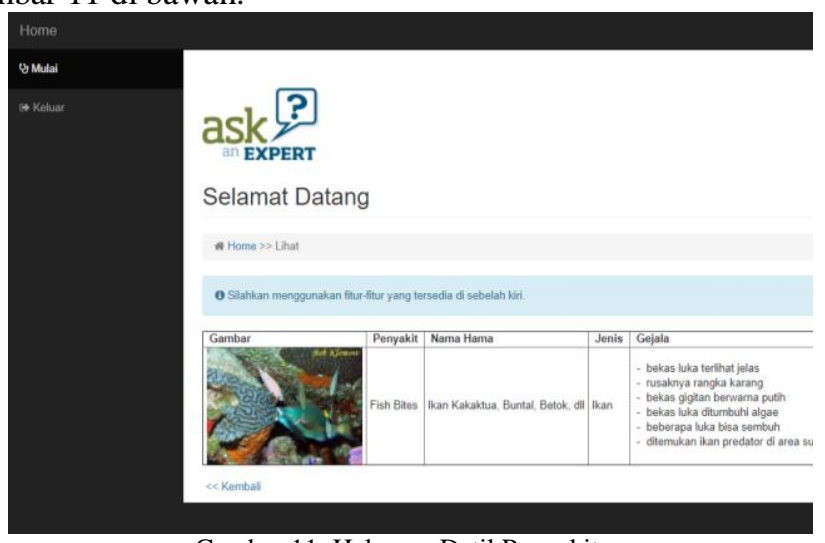

Gambar 11. Halaman Detil Penyakit

\section{Menu Perbaiki Penyakit}

Halaman perbaiki penyakit merupakan halaman yang penting dimana kita bisa mengimplementasikan metode Ripple Down Rules (RDR). Melalui menu ini kita bisa mengubah nama penyakit, nama hama, jenis hama dan gejala suatu penyakit. Tampilannya bisa kita lihat pada Gambar 12 di bawah.

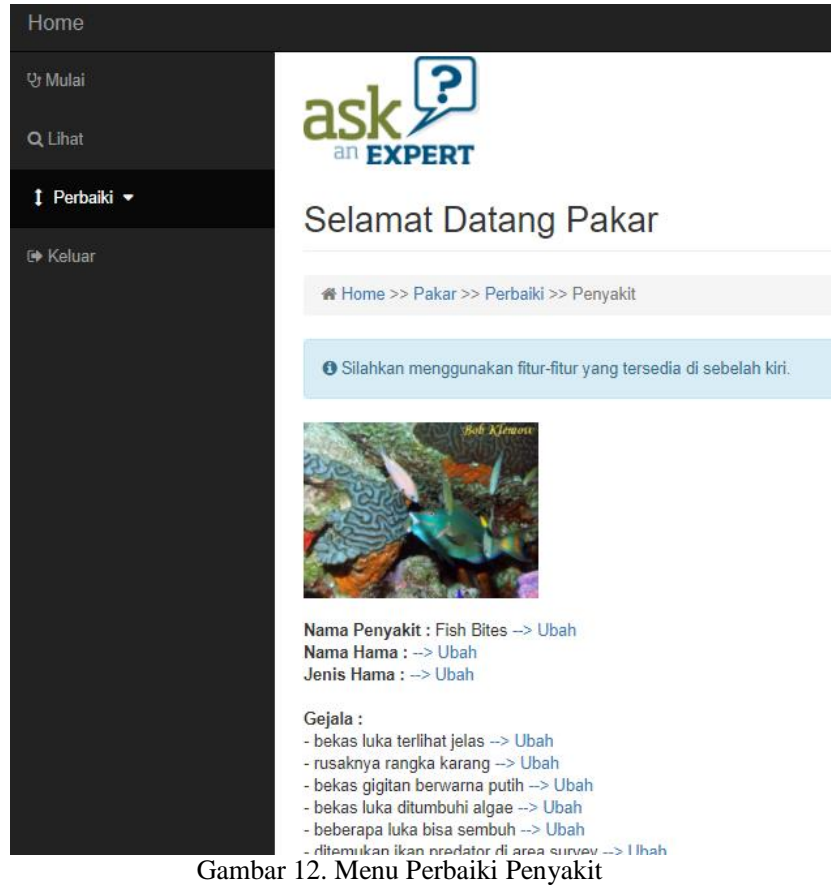

\section{Menu Perbaiki Gejala}

Halaman perbaiki gejala merupakan halaman yang penting dimana kita bisa mengimplementasikan metode Ripple Down Rules (RDR). Melalui menu ini kita bisa mengubah nama penyakit, nama hama, jenis hama dan gejala suatu penyakit. Tampilannya bisa kita lihat pada Gambar 13 di bawah.

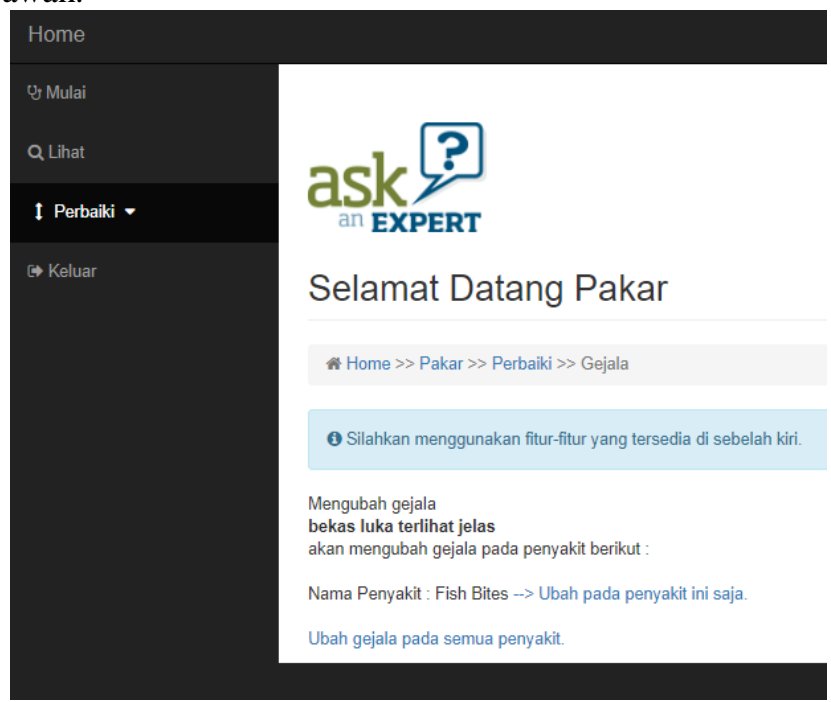

Gambar 13. Menu Perbaiki Gejala

\section{E. Menu Konsultasi}

Menu konsultasi adalah menu yang tampil ketika pakar dan pengguna menekan tombol mulai pada menu pakar atau menu pengguna seperti pada Gambar 14 di bawah. Menu ini digunakan untuk berkonsultasi dengan sistem tentang gejalagejala yang ditemui pada terumbu karang untuk menemukan penyakit yang menyerang. 

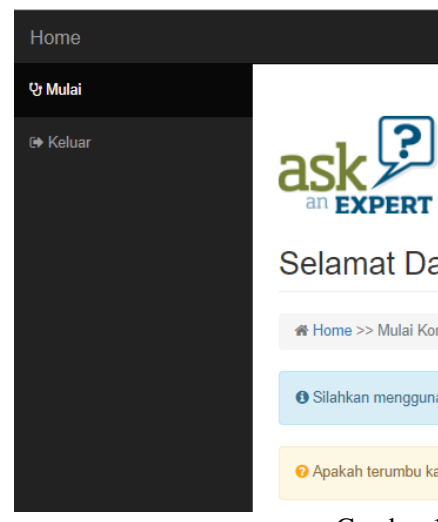

Selamat Datang

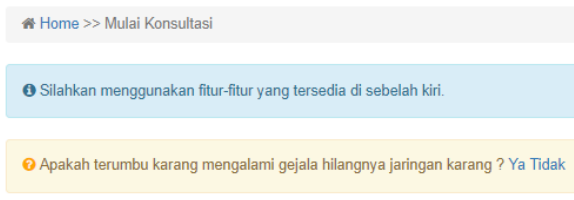

Gambar 14. Menu konsultasi

\section{F. Menu Hasil Konsultasi}

Merupakan menu yang tampil setelah melakukan proses konsultasi kepada sistem seperti pada Gambar 15 di bawah. Tampilan ini berisi penjelasan tentang penyakit, hama yang menyerang dan gejala-gejala yang diinputkan oleh pakar dan pengguna.

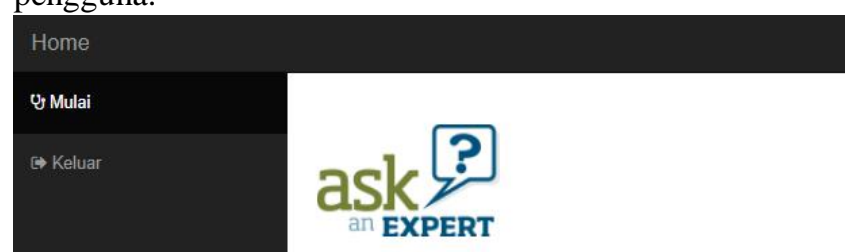

\section{Selamat Datang}

* Home >> Mulai Konsultasi $\gg$ Hasil Konsultasi

B Silahkan menggunakan fitur-fitur yang tersedia di sebelah kiri. 3. Silahkan monggunakan fitur-itur yang tersedia di sebelah kini. algae overgrowth

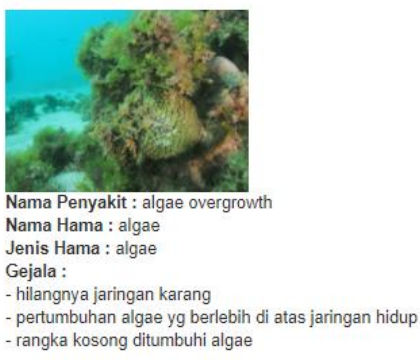

Gambar 15. Menu hasil konsultasi

\section{KESIMPULAN}

Kesimpulan yang dapat diambil berdasarkan hasil implementasi dan analisis sistem untuk program penerapan metode Ripple Down Rules (RDR) dalam sistem pakar indentifikasi penyakit terumbu karang adalah sebagai berikut:

1. Sistem dapat mengajukan pertanyaan yang lebih sedikit kepada pengguna untuk menemukan suatu penyakit. 2. Metode Ripple Down Rules (RDR) dapat digunakan untuk proses pengaturan dan pemeliharaan sistem pakar. Metode ini memiliki kemampuan untuk mengatur ulang aturanaturan yang terdapat dalam basis aturan berdasarkan faktafakta yang ditambah, diubah maupun diperbaiki oleh pakar dalam sistem pakar ini.
3. Sistem mampu menjaga konsistensi fakta dan aturan pada proses penambahan, perbaikan dan penghapusan didalam sistem.

\section{DAFTAR PUSTAKA}

[1] Durkin John, Expert Systems Design and Development, University of Akron, 1994.

[2] Sadarun, B., Pedoman Pelaksanaan Transplantasi Karang, Direktorat Konservasi dan Taman Nasional Laut dan Direktorat Jendral KP3K, DKP, Jakarta, 2006.

[3] Kurman, W.B., White-band disease in Acropora palmata: implications for the structure and growth of shallow reefs, Bull. Mar. Sci., 2007, 32: 639-643.

[4] Willis, B.L., Page, C.A., Dinsdale, E.A., Coral Disease on the Great Barrier Reef., Coral Disease and Health., (Rosenberg E, \& Loya Y, eds)., 2004, pp 69-104., Springer-Verlag., Berlin.

[5] Kellogg C.A., Piceno Y.M., Tom L.M., De Santis T.Z., Andersen G.L., Gray M.A. 2014. Comparing Bacterial Community Composition of Healthy and Dark Spot-Affected Siderastrea siderea in Florida and the Caribbean. Plos one Vol. 9. Issue 10. www.plosone.org. [Desember 2014]

[6] Raymundo, L.J., Couch, C.S. and Harvell, C.D., Coral Disease Handbook: Guidelines for Assessment, Monitoring \& Management. Coral Reef Targeted Research and Capacity Building for Management Program, The University of Queensland, Australia, 2008.

[7] Borger, J.L., and Steiner, S.C.C., The Spatial Temporal Dynamik of Coral Diseases in Dominica, Eest Indies. Bulletin of Marine Science., 2005, 77(1):137-154.

[8] Muller E.M., Raymundo L.J., Willis B.L., Haapkyla J., Yusuf S. Wilson JR., Harvell DC., Coral Health and Disease In The Spermonde Archipelago and Wakatobi, Sulawesi, 2012: 147-159.

[9] Giarratano, J. C., Riley, G.D., Expert System Principles and Programming Fourth Edition, Canada: Course Technology, 2005.

[10] Martin, J., \& Oxman, S., Building Expert System., New Jersey : Prentice Hall, 1998.

[11] Campton, P., Peters, L., Edwards, G., Lavers, T.G., Experience with Ripple-Down Rules, University of New South Wales, Sydney, Australia, 2005.

[12] Jursic, M. Mozetic, I., Learning Ripple Down Rules For Efficient Lemmatization, Department of Knowledge Technologies, Jožef Stefan Institute, 2010.

[13] Buchanan, Bruce G., "A (Very) Brief History of Artificial Intelligence" (PDF), AI Magazine, 2007, pp. 53-60.

[14] Bratko, Production Rules, 4th ed, Chapter 15, 2016: 343

[15] Edy Setyawan, Estradivari, Identifikasi Penyakit dan Gangguan Kesehatan pada Terumbu Karang, Terangi Foundation, Presentation: 2016. 